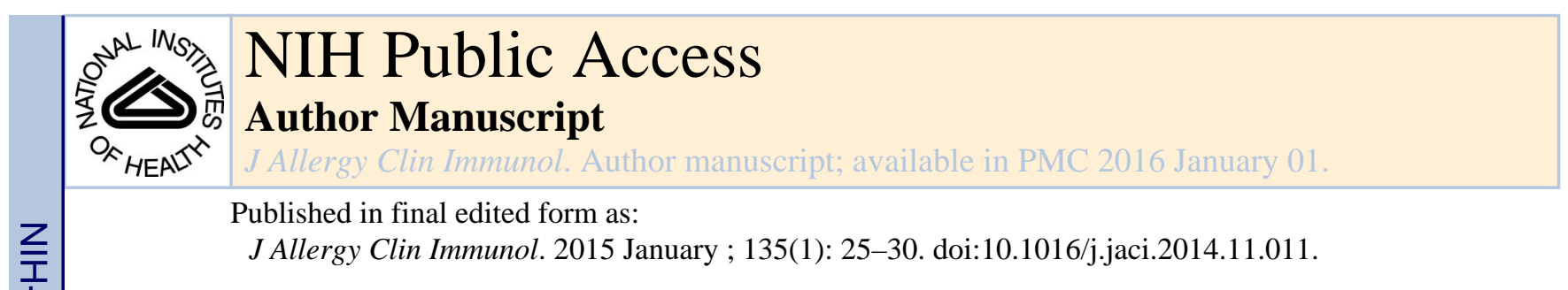

\title{
The Microbiome in Asthma
}

\author{
Yvonne J. Huang, MD and Homer A. Boushey, MD \\ Division of Pulmonary, Critical Care, Allergy, \& Sleep Medicine, Department of Medicine, \\ University of California, San Francisco
}

\section{Abstract}

The application of recently developed sensitive, specific, culture-independent tools for identification of microbes is transforming concepts of microbial ecology, including concepts of the relationships between the vast, complex populations of microbes associated with ourselves and with states of health and disease. While most work initially focused on the community of microbes (microbiome) in the gastrointestinal tract and its relationships to gastrointestinal disease, interest has expanded to include study of the relationships of the microbiome of the airways to asthma and its phenotypes, and to the relationships between the gastrointestinal microbiome, development of immune function, and predisposition to development of allergic sensitization and asthma. We here provide our perspective on the findings of studies of differences in the airway microbiome in patients with asthma vs. healthy subjects, and of studies of relationships between environmental microbiota, gut microbiota, immune function, and the development of asthma, and additionally provide our perspective on how these findings suggest in broad outline a rationale for approaches involving directed manipulation of the gut and airway microbiome for treatment and prevention of allergic asthma.

\section{Keywords}

microbiome; microbiota; bacterial community composition; immune function; allergy; asthma

\section{Introduction}

Our conceptions of the role of microbes in human health and disease have been transformed by the development of sensitive, culture-independent methods based on amplifying and sequencing genetic material unique to prokaryotes. Use of these methods has established that virtually every anatomical compartment in communication with the external environment is colonized by a distinct microbial community. ${ }^{1}$ While most is known about

(C) 2014 American Academy of Allergy, Asthma amp; Immunology. All rights reserved.

Corresponding author: Professor of Medicine, University of California, San Francisco, Medicine - Allergy \& Immunology Division, 505 Parnassus Avenue, Room M-1292, Box 0130, San Francisco, CA 94143-0130, UNITED STATES, 415-476-8019, Mobile: 415-602-7062, FAX: 415-502-6235, homer.boushey@ucsf.edu.

Publisher's Disclaimer: This is a PDF file of an unedited manuscript that has been accepted for publication. As a service to our customers we are providing this early version of the manuscript. The manuscript will undergo copyediting, typesetting, and review of the resulting proof before it is published in its final citable form. Please note that during the production process errors may be discovered which could affect the content, and all legal disclaimers that apply to the journal pertain. 
the relationships to health and disease of the bacterial microbiome, attention is now also being directed to other microbial constituents, such as fungi and viruses.

Applying these newly developed culture-independent methods for microbial detection to the study of lung disease is an intuitive extension of the well-established interest in the role of microbial infection in acute bronchitis, chronic obstructive pulmonary disease, cystic fibrosis, and asthma. It was (and is) also driven by recognition of the continuous exposure of the lower airways to airborne matter, as well as to secretions from the upper respiratory and gastrointestinal systems, providing ample opportunity for microbes to become established. Some evidence indeed suggests that a distinct bacterial microbiome populates the subglottic airways in health, ${ }^{2,3}$ and a larger, more persuasive body of evidence suggests that the microbiome of the lower airways differs distinctly in the obstructive lung diseases, including asthma. ${ }^{4,5}$

In addition to the recent attention paid to understanding the respiratory microbiome, many studies of the microbiome in asthma have focused on the relationships of the environmental and gastrointestinal microbiome to the development of immune function in infancy. This focus was prompted by epidemiologic findings showing an inverse relationship between rates of childhood asthma and exposure in infancy to microbially rich environments (e.g., presence of older siblings, ${ }^{6}$ growing up on a farm with livestock, ${ }^{7-9}$ ingestion of nonpasteurized milk, ${ }^{10}$ presence of two or more dogs in the home). ${ }^{11}$ This focus was furthered by studies showing gut microbiota to influence the rate and pattern of maturation of immune function in early life, ${ }^{12-15}$ and by the idea that the entry of environmental bacteria could be through oral ingestion. Alterations in respiratory tract immune function are at least theoretically linked to the immunomodulatory activity of gut microbiota through the concept of a "common mucosal response". ${ }^{16-18}$ This proposes that antigen presentation at one mucosal site stimulates migration of lymphoid cells to other mucosal sites, shaping immune responsiveness at those sites as well. Regardless of the anatomic pathways by which microbiota influence asthma - gastrointestinal, respiratory, or quite possibly both - the great challenge of understanding microbiome-host interactions will be definition of the mechanisms responsible, a challenge magnified by the complexities of host genomics and immunology, the impact of environmental factors not yet recognized as relevant, and the clinical heterogeneity of asthma itself.

The breadth of studies examining the role of niche-specific microbiota in asthma is large and cannot be covered comprehensively in this perspective. Rather, our intent is to highlight recent insights into relationships between the bronchial, environmental, and gastrointestinal microbiome and asthma. We also allude to potential strategies, some borrowed from other fields of microbiome investigation, that may prove useful in identifying the mechanisms by which endogenous microbiota affect asthma.

\section{The airway microbiome in asthma}

The idea that bronchial infection might underlie asthma was fostered by epidemiologic studies reporting an association between the development of bronchitis or pneumonia during community outbreaks of Chlamydophila pneumoniae and adult onset asthma. ${ }^{19}$ These 
findings echoed earlier reports that treatment with a macrolide antibiotic was effective in patients with "chronic infectious asthma" 20 - the term then applied to asthma associated with chronic mucus hypersecretion that worsens with asthma exacerbations. Later reports of Mycoplasma pneumoniae or Chlamydophila pneumoniae detection by PCR in bronchial biopsies from a higher proportion of asthmatic than healthy patients, along with reported clinical improvements from prolonged clarithromycin treatment of subjects PCR-positive for these organisms, seemed to confirm the idea of an infectious component to asthma's pathogenesis in some patients. ${ }^{21-23}$ These findingshave not been widely confirmed, ${ }^{24,} 25$ but the conflicting results of different studies may relate in part to differences in the proportion of asthmatic subjects enrolled with airways colonized or infected by bacteria responsive to prolonged antibiotic therapy. ${ }^{26}$ In other words, bronchial colonization or infection by bacteria responsive to antibiotic treatment may represent an asthma phenotype without distinguishing clinical features, at least without distinguishing clinical features we have learned to identify..

That developing asthma may be a function of "bad luck" due to early airway colonization by bacteria that directly mediate the disease is one possible interpretation of findings from the Copenhagen Birth Cohort Study. Culture of Moraxella catarrhalis, Haemophilus influenzae, or Streptococcus pneumoniae from the oropharynx of one-month old infants was associated with a significant increase in their odds ratio for childhood asthma. ${ }^{27}$ The same organisms are also strongly associated with asthma exacerbations. ${ }^{28}$ While these species have pathogenic potential, it is also possible that their growth reflects differences in immune function in the infants infected. ${ }^{29}$ A recent study of 308 children (half with asthma) whose nasal secretions were analyzed by PCR-based methods for five consecutive weeks of the autumn season for two consecutive years revealed that coincident identification of Moraxella catarrhalis or Streptococcus pneumoniae was associated with greater severity of respiratory tract illnesses, including asthma exacerbations, attributed to rhinovirus infection. ${ }^{30}$ Not all bacteria in the airways worsen the severity of virus-induced respiratory infections, however. For example, nasal administration of Lactobacillus rhamnosus induces protection against respiratory syncytial virus infection in mice. ${ }^{31}$

Studies of the possible role of a bacterial microbiome in established asthma relied on methods based on detection and sequence analysis of the conserved gene for bacterial $16 \mathrm{~S}$ ribosomal RNA in bronchial samples from asthmatic and non-asthmatic individuals. ${ }^{5,}, 32,33$ Despite differences in the types of specimens and 16S rRNA-based technologies used, the results of these studies have been generally concordant in their finding that Proteobacteria a large phylum that includes many known respiratory pathogens - are more prevalent in the lower airways of asthmatics compared to those of healthy controls. While two of these studies $^{5,32}$ involved asthmatics regularly taking inhaled corticosteroids (ICS), a small study of induced sputum samples from mild asthma patients, most of whom were not regularly taking ICS, similarly reported a greater prevalence of Proteobacteria, compared to healthy controls. ${ }^{33}$ This suggests that altered airway microbiota composition may be a feature of asthma itself and not simply a reflection of the immunomodulatory effects of ICS treatment.

Outcomes of clinical interest have been associated with features of the airway microbiome in asthmatics. A study of asthmatics treated with a standardized dose of ICS showed greater 
airway bacterial diversity to correlate with greater airway hyper-responsiveness. ${ }^{32}$ Among the subjects randomized to treatment with clarithromycin in this study, those demonstrating an improvement in airway hyper-responsiveness had higher bacterial diversity at baseline.

Relationships between the airway microbiome and disease features have also been examined in patients with in severe asthma. Different clinical phenotypes of severe asthma have been described, suggesting the possible involvement of alternate mechanistic pathways ${ }^{34,35}$, as has been surmised for asthma in general. A preliminary analysis of the bronchial microbiome in these subjects, poorly controlled despite high-dose ICS therapy, noted significant relationships between different bacterial community profiles and features such as body-mass index and measures of asthma control. ${ }^{36} \mathrm{~A}$ similar study of sputum bacterial composition in 28 treatment-resistant asthmatics found that the relative abundance of $M$. catarrhalis, Haemophilus, or Streptococcus spp. correlated with worse lung function and higher sputum neutrophil counts and IL-8 concentrations. ${ }^{37}$

Observations from descriptive clinical microbiome studies like these invite hypotheses for mechanism-oriented investigations of how the airway microbiome affects asthma development in model systems. Given asthma's heterogeneity, however, descriptive, or "discovery-driven" human studies will remain key for uncovering targets and pathways for further investigation As was highlighted in an NHLBI workshop on the future of lung microbiome investigations, "discovery-driven" studies and "hypothesis-driven" research are necessarily complementary. ${ }^{38}$ The use of high-throughput molecular techniques to characterize microbiota often generates large but rich datasets. "Discovery-driven" investigation refers to a data-driven approach, often using exploratory statistics, to uncover potential targets of interest and derive new hypotheses. This can transpire concurrently with addressing the initial research questions and hypotheses that prompted the investigation.

An example of these approaches is a study of airway microbiome relationships to corticosteroid-responsiveness among asthmatic patients. ${ }^{39}$ Bacterial profiles from BAL were examined from 39 asthmatics and 12 healthy controls. Corticosteroid-responsiveness was characterized by lung function response to a course of oral prednisone. Differences in bacterial composition between corticosteroid-sensitive vs. corticosteroid -resistant asthmatics were not readily discerned, but potentially existed among a subset of subjects. Complementary in vitro studies showed impairment of the response to dexamethasone of monocytes and macrophages co-cultured with Haemophilus parainfluenzae, found in some of the corticosteroid-resistant asthmatics, but not with Prevotella melaninogenica, a presumed commensal bacterium found in healthy subjects. This study highlights the challenges but also the importance of integrating "discovery-driven" and "hypothesisdriven" investigations.

Finally, an intriguing recent murine-based study highlights the contribution of lung microbiota establishment in early life on the development of allergic airway inflammation. ${ }^{40}$ After birth, development-related changes in lung bacterial load and community composition were associated with decreased airway responses to aeroallergen exposure. Interestingly, this tolerance was not associated with the existing presence of high numbers of regulatory Tcells (Treg) in the lung at birth, but rather with the development of a different Treg subset 
that seemed to require microbial presence during a critical early window after birth. These findings suggest that 1) establishment of a lung microbiome occurs and is a dynamic process after normal birth, and 2) the relationship between microbiota and lung-specific immune development is not static. Whether these dynamics are influential in the subsequent development of asthma in childhood and beyond remains to be seen.

\section{The role of environmental and gut microbiota in asthma}

Many of the early life practices, conditions, and exposures associated with lower rates of allergy and asthma seem likely to increase the burden and diversity of exposure to microbes in infancy. These include residence in countries with a predominantly agrarian economy, ${ }^{41}$ having multiple older siblings, ${ }^{6}$ breastfeeding, ${ }^{42}$ growing up in close contact with farm animals, ${ }^{7-9}$ early day care attendance. ${ }^{43}$ consuming farm milk or contaminated water, ${ }^{10}, 44$ and growing up with pet dogs. ${ }^{11}$ Some consistent findings across such studies are that the reduction in risk of sensitization is not allergen-specific, the impact of exposure is greatest in the first year of life, and that the impact does not correlate well with environmental sample concentrations of animal allergen, endotoxin, muramic acid, or egosterol. That the protection against allergy or asthma is so often associated with something ingested suggests that the gastrointestinal tract is at least one site via which protection is mediated. This idea is reinforced by reports of differences in stool microbiota of babies who go on to develop allergic sensitization, having fewer Lactobacilli, Bacteroidetes, and Bifidobacteria and more coliforms, Clostridia, and Enterococci. ${ }^{45-48}$

Studies in mice provide strong support for the concept that bacterial community composition of the gastrointestinal tract can shape developing immune function to foster or protect against allergic sensitization. The allergic airway inflammation induced by OVA sensitization and challenge is exaggerated in germ-free (GF) mice compared to isogenic specific pathogen-free (SPF) mice, but this exaggeration is reversed by transfer colonization of gut microbiota from SPF mice into GF mice, ${ }^{49}$ so long the colonization occurs in early life. ${ }^{12}$ Clues as to the specific bacteria associated with this protective effect include studies showing that feeding a mix of Clostridium strains to SPF BALB/c mice induced expansion of Treg cells in the colonic mucosa, and reduced systemic IgE production after OVA sensitization..$^{50}$ Oral treatment of BALB/c mice with Lactobacillus reuteri also induced expansion of Treg cells in the circulation, spleen, and mediastinal nodes, and reduced inflammatory response to OVA challenge in sensitized mice. ${ }^{51}$ Because of the role of Th17 cells in mediating defense at mucosal surfaces, much attention has been accorded to the finding that feeding of a single bacterial species, segmented filamentous bacterium, was sufficient to induce a striking expansion of Th17 cells in the lamina propria of mice. ${ }^{52}$

A recent study in mice has shown that direct ingestion of bacteria is not absolutely necessary to induce profound changes in the gut microbiome that in turn induce changes in immune function. The feeding of a diet high in fermentable fiber content altered the ratio of gut Firmicutes to Bacteroidetes, increased the levels of circulating short chain fatty acids, and, through their alteration of dendritic cell capacity to promote Th2 cell effector function, protected against allergic inflammation in the lung. ${ }^{53}$ The authors concluded that these data 
"suggest a cellular mechanism for an intestinal-bone marrow-lung axis in controlling airway inflammation."

\section{Relationships of gut microbiota to response to viral respiratory infection}

In addition to shaping the risk of allergic sensitization, gut microbiota may also shape responses to viral respiratory infection in infancy. The importance of such infections in early life to asthma development was strikingly shown in the Childhood Origins of Asthma Study (COAST), a birth cohort study of children of parents with allergies or asthma. Among these children, becoming ill from a viral respiratory infection, especially rhinovirus-related, in the first year of life was associated with a greater than 10-fold increase in the odds ratio for having asthma at age six yrs. ${ }^{54}$ Paired with murine studies showing that viral infection in infancy can result in life-long changes in airway function, ${ }^{55}$ this invites the question as to whether enhancing the response to viral respiratory infections in infancy might be a strategy for asthma prevention. 56

These considerations heighten the potential importance of animal-based studies demonstrating relationships between gut microbiota and the response to viral infection. ${ }^{57-59}$ Gut microbiota regulate immune defense against respiratory influenza A infection in C57BL/6 mice. ${ }^{57}$ Feeding L. casei to BALB/c mouse pups before inoculation with influenza virus lowered viral titers in nasal lavage fluid, increased pulmonary natural killer cell activity, and nearly tripled rate of survival. ${ }^{59}$ Oral administration of L. rhamnosus to $\mathrm{BALB} / \mathrm{c}$ mice also modulated respiratory anti-viral immunity triggered by TLR3 activation. ${ }^{58}$ Finally, based on prior observations that close contact with household pet dogs in the first year of life is protective against allergic sensitization ${ }^{11}$ and that the bacterial content of household dust from homes with and without pets differs, ${ }^{60}$ investigators recently demonstrated that feeding mice house dust from dog-associated homes attenuated lung inflammation from allergic challenge and also from inoculation with respiratory syncytial virus. ${ }^{61}$ Analysis of the cecal microbiota of protected mice showed an increase in Lactobacillus johnsonii, which when fed to other mice replicated the protection against allergic and infectious inflammation of the lung. Although this study focused on the effects of a single bacterial species recovered from the ceca of mice fed dust from a dog-occupied home, the overall approach demonstrates the promise of combined "discovery-driven" and "hypothesis-driven" approaches to glean mechanistic insights into microbiome-host relationships in asthma.

Feeding bacteria or bacterial products may also affect the response to viral respiratory infection in humans, for administration of L. acidophilus and B. animalis to 3 to 5 year-old children resulted in reduced fever, rhinorrhea, cough, and antibiotic use. ${ }^{62}$ Oral treatment with a mixture of lyophilized bacterial extracts (OM-85BV) for the first 10 days of 3 consecutive months also reduced the cumulative number of respiratory infections and the number and duration of wheezing episodes. ${ }^{63}$ Similar findings have been observed in vulnerable preterm infants, in whom prebiotic and probiotic supplementation was found to prevent illness from rhinovirus infection. ${ }^{64}$ 


\section{Interaction of exposures to environmental allergens and microbes?}

The observations summarized above can be interpreted as suggesting a causal pathway linking environmental exposures in early infancy to the development of allergy and asthma: (1) environmental exposures shape the composition of gut microbiota; (2) gut microbiota shape the rate and pattern of development of immune function; and (3) differences in immune function shape the nature and intensity of responsiveness to allergens and viruses encountered. A modification of this argument would be that an additional, or possibly even more relevant, site of microbial colonization is the respiratory tract. ${ }^{31,40}$

Another modification of this argument - that coincident exposure to certain microbes along with allergen exposure may inhibit induction of allergic sensitization - is suggested by a birth cohort study of infants raised in "inner city" neighborhoods with high rates of poverty. The high rate of morbidity from allergic asthma in inner city children has been attributed to the high levels of cockroach and mouse allergen found in inner city households. ${ }^{65,66}$ and have been cited as evidence contradicting the "Hygiene Hypothesis" on the basis of the presumption that inner city households are less hygienic than households in less impoverished areas. ${ }^{67}$

The birth cohort study that presented the opportunity to examine the relevance of the "Hygiene Hypothesis" in an inner-city population was the still ongoing "Urban Environment and Childhood Asthma ("URECA") study of inner city children. ${ }^{68}$ Dust collected over the first three years of life from the households of the children enrolled was analyzed for bacterial as well as allergen content. Surprisingly, the highest rates of atopic sensitization and recurrent, presumably virus-induced wheeze at age three years were found in the children exposed to the lowest levels of cockroach, mouse, and cat allergen and the lowest levels of bacterial diversity in their first year of life, whereas the lowest rates of atopy and wheezing were found in those who had been exposed to the highest levels of these allergens and of bacterial diversity. ${ }^{69}$ The bacteria associated with protection were largely members of the Bacteroidetes and Firmicutes phyla (e.g., Rikenellaceae, Porphomonodaceae,

Lachnospiraceae, Prevotellaceae, etc.). A possible interpretation is that the bacteria ingested (or inhaled) served as a kind of tolerance-inducing adjuvant for the allergens ingested or inhaled, an idea echoed by a recent report that commensal bacteria protect against food allergen sensitization. ${ }^{70}$

\section{Microbiome-host relationships in asthma: key concepts and future challenges}

The concept of a "common mucosal immune system" rests on the premise that there is crosstalk between human mucosal compartments and that microbially driven differences in mucosal immune function may be shared across sites. That local immune function, both innate and adaptive, also influences microbiome constitution is also likely true. Once microbes enter a niche and become established, a balance must be struck that maintains functional homeostasis between microbiome and host. This balance is constantly challenged by a number of factors that can alter or perturb microbiota composition, leading to a state of 
"dysbiosis" or imbalance in the microbial community, which is now recognized to characterize common airway diseases including asthma.

Dissecting the role of the microbiome in asthma is challenged by the heterogeneity of the disease at multiple levels (Figure 1). These levels include asthma's clinical and inflammatory heterogeneity, genetic factors that contribute to asthma risk, ${ }^{71}$ and the multiplicity of immune pathways involved in asthma. For single-nucleotide polymorphisms identified in asthma susceptibility genes, the functional consequences of most remain unknown. Surmised roles for these genes include in lung development ${ }^{72}$ and immune functions that could shape responses within the airway microenvironment that affect asthma. Finally, the potential effects of environmental exposures on gene function, immune responses, as well as microbiota composition add further complexity. As with genetics, mechanistic consequences of identified alterations in airway microbiota composition in asthma remain unclear, and it is quite possible that the role of the microbiome (airway or gut) has a greater role in certain aspects or phenotypes of the disease than others (e.g., the development of allergic or non-allergic asthma, treatment-resistant asthma).

A way out of the quandary of complexity in examining relationships between microbes, genes, and environment in asthma causation is to look again at the approaches used in studies of relationships between the gastrointestinal microbiome and gastrointestinal disease. An example is Turnbaugh et al.'s study of fecal microbiota of twins concordant for leanness and obesity. ${ }^{73}$ Their findings showed that between-twin differences in microbial community composition were not necessarily reflected in the genes and pathways they express. The implication is that perturbations in core microbial functions, rather than in core microbial composition, are key to mediation of disease. For “discovery-driven' research, we are thus brought to the necessity of "Omics", leveraging these tools to identify microbiomeassociated targets and pathways relevant to the driving research questions. Synthesis of the data will require integrating the findings from careful study of phenotypic features of disease in the individuals studied and careful study of the microbiota of their respiratory and gastrointestinal tracts with information gathered through "-omic" analysis of host and microbiome, genome, transcriptome, proteome, and metabolome. This work has already started with, for example, the integration of predictive metagenomic analyses of taxa of interest, ${ }^{74}$ to predict gene functions and their involved pathways to infer biological higherlevel functions encoded by microbiota members. The findings from this integrated approach will lead to the generation of more refined hypotheses for "hypothesis-driven" research, which initially must be done in model systems, including animals and culture-based approaches. To progress from these studies to clinical studies of oral or aerosol administration of microbiota for treatment and especially for prevention of asthma - which will necessarily involve enrollment of pregnant women or of newborn infants - will likely require overcoming ethical, legal, and cultural hurdles as high as the scientific ones we currently face.

\section{Abbreviations}

BAL Bronchoalveolar lavage 
COAST Childhood Origins of Asthma Study

GF Germ-free

ICS Inhaled corticosteroid

IgE Immunoglobulin E.

OVA Ovalbumin

SPF Specific pathogen-free

Treg T-regulatory

\section{References}

1. Structure, function and diversity of the healthy human microbiome. Nature. 2012; 486:207-214. [PubMed: 22699609]

2. Morris A, Beck JM, Schloss PD, Campbell TB, Crothers K, Curtis JL, et al. Comparison of the respiratory microbiome in healthy nonsmokers and smokers. Am J Respir Crit Care Med. 2013; 187:1067-1075. [PubMed: 23491408]

3. Charlson ES, Bittinger K, Haas AR, Fitzgerald AS, Frank I, Yadav A, et al. Topographical continuity of bacterial populations in the healthy human respiratory tract. Am J Respir Crit Care Med. 2011; 184:957-963. [PubMed: 21680950]

4. Erb-Downward JR, Thompson DL, Han MK, Freeman CM, McCloskey L, Schmidt LA, et al. Analysis of the lung microbiome in the "healthy" smoker and in COPD. PLoS One. 2011; 6:e16384. [PubMed: 21364979]

5. Hilty M, Burke C, Pedro H, Cardenas P, Bush A, Bossley C, et al. Disordered microbial communities in asthmatic airways. PLoS One. 2010; 5:e8578. [PubMed: 20052417]

6. Strachan DP. Hay fever, hygiene, and household size. BMJ. 1989; 299:1259-1260. [PubMed: 2513902]

7. Ege MJ, Mayer M, Normand AC, Genuneit J, Cookson WO, Braun-Fahrlander C, et al. Exposure to environmental microorganisms and childhood asthma. N Engl J Med. 2011; 364:701-709. [PubMed: 21345099]

8. Heederik D, von Mutius E. Does diversity of environmental microbial exposure matter for the occurrence of allergy and asthma? J Allergy Clin Immunol. 2012; 130:44-50. [PubMed: 22502794]

9. Riedler J, Braun-Fahrlander C, Eder W, Schreuer M, Waser M, Maisch S, et al. Exposure to farming in early life and development of asthma and allergy: a cross-sectional survey. Lancet. 2001; 358:1129-1133. [PubMed: 11597666]

10. Waser M, Michels KB, Bieli C, Floistrup H, Pershagen G, von Mutius E, et al. Inverse association of farm milk consumption with asthma and allergy in rural and suburban populations across Europe. Clin Exp Allergy. 2007; 37:661-670. [PubMed: 17456213]

11. Ownby DR, Johnson CC, Peterson EL. Exposure to dogs and cats in the first year of life and risk of allergic sensitization at 6 to 7 years of age. JAMA. 2002; 288:963-972. [PubMed: 12190366]

12. Olszak T, An D, Zeissig S, Vera MP, Richter J, Franke A, et al. Microbial exposure during early life has persistent effects on natural killer T cell function. Science. 2012; 336:489-493. [PubMed: 22442383]

13. Rautava S, Luoto R, Salminen S, Isolauri E. Microbial contact during pregnancy, intestinal colonization and human disease. Nat Rev Gastroenterol Hepatol. 2012; 9:565-576. [PubMed: 22890113]

14. Russell SL, Gold MJ, Hartmann M, Willing BP, Thorson L, Wlodarska M, et al. Early life antibiotic-driven changes in microbiota enhance susceptibility to allergic asthma. EMBO Rep. 2012; 13:440-447. [PubMed: 22422004] 
15. Erturk-Hasdemir D, Kasper DL. Resident commensals shaping immunity. Curr Opin Immunol. 2013; 25:450-455. [PubMed: 23830047]

16. Czerkinsky C, Prince SJ, Michalek SM, Jackson S, Russell MW, Moldoveanu Z, et al. IgA antibody-producing cells in peripheral blood after antigen ingestion: evidence for a common mucosal immune system in humans. Proc Natl Acad Sci U S A. 1987; 84:2449-2453. [PubMed: 3470804]

17. Kiyono H, Fukuyama S. NALT- versus Peyer's-patch-mediated mucosal immunity. Nat Rev Immunol. 2004; 4:699-710. [PubMed: 15343369]

18. Mestecky J. The common mucosal immune system and current strategies for induction of immune responses in external secretions. J Clin Immunol. 1987; 7:265-276. [PubMed: 3301884]

19. Hahn DL, Dodge RW, Golubjatnikov R. Association of Chlamydia pneumoniae (strain TWAR) infection with wheezing, asthmatic bronchitis, and adult-onset asthma. JAMA. 1991; 266:225230. [PubMed: 2056624]

20. Kaplan MA, Goldin M. The use of triacetyloleandomycin in chronic infectious asthma. Antibiot Annu. 1958; 6:273-276. [PubMed: 13637749]

21. Good JT Jr, Kolakowski CA, Groshong SD, Murphy JR, Martin RJ. Refractory asthma: importance of bronchoscopy to identify phenotypes and direct therapy. Chest. 2012; 141:599-606. [PubMed: 21835905]

22. Kraft M, Cassell GH, Henson JE, Watson H, Williamson J, Marmion BP, et al. Detection of Mycoplasma pneumoniae in the airways of adults with chronic asthma. Am J Respir Crit Care Med. 1998; 158:998-1001. [PubMed: 9731038]

23. Kraft M, Cassell GH, Pak J, Martin RJ. Mycoplasma pneumoniae and Chlamydia pneumoniae in asthma: effect of clarithromycin. Chest. 2002; 121:1782-1788. [PubMed: 12065339]

24. Black PN, Blasi F, Jenkins CR, Scicchitano R, Mills GD, Rubinfeld AR, et al. Trial of roxithromycin in subjects with asthma and serological evidence of infection with Chlamydia pneumoniae. Am J Respir Crit Care Med. 2001; 164:536-541. [PubMed: 11520711]

25. Sutherland ER, King TS, Icitovic N, Ameredes BT, Bleecker E, Boushey HA, et al. A trial of clarithromycin for the treatment of suboptimally controlled asthma. J Allergy Clin Immunol. 2010; 126:747-753. [PubMed: 20920764]

26. Wong EH, Porter JD, Edwards MR, Johnston SL. The role of macrolides in asthma: current evidence and future directions. Lancet Respir Med. 2014; 2:657-670. [PubMed: 24948430]

27. Bisgaard H, Hermansen MN, Buchvald F, Loland L, Halkjaer LB, Bonnelykke K, et al. Childhood asthma after bacterial colonization of the airway in neonates. N Engl J Med. 2007; 357:14871495. [PubMed: 17928596]

28. Bisgaard H, Hermansen MN, Bonnelykke K, Stokholm J, Baty F, Skytt NL, et al. Association of bacteria and viruses with wheezy episodes in young children: prospective birth cohort study. BMJ. 2010; 341:c4978. [PubMed: 20921080]

29. von Mutius E. Of attraction and rejection--asthma and the microbial world. N Engl J Med. 2007; 357:1545-1547. [PubMed: 17928604]

30. Kloepfer KM, Lee WM, Pappas TE, Kang TJ, Vrtis RF, Evans MD, et al. Detection of pathogenic bacteria during rhinovirus infection is associated with increased respiratory symptoms and asthma exacerbations. J Allergy Clin Immunol. 2014; 133:1301-1307. 7 e1-7 e3. [PubMed: 24698319]

31. Tomosada Y, Chiba E, Zelaya H, Takahashi T, Tsukida K, Kitazawa H, et al. Nasally administered Lactobacillus rhamnosus strains differentially modulate respiratory antiviral immune responses and induce protection against respiratory syncytial virus infection. BMC Immunol. 2013; 14:40. [PubMed: 23947615]

32. Huang YJ, Nelson CE, Brodie EL, Desantis TZ, Baek MS, Liu J, et al. Airway microbiota and bronchial hyperresponsiveness in patients with suboptimally controlled asthma. J Allergy Clin Immunol. 2011; 127:372-381. e1-e3. [PubMed: 21194740]

33. Marri PR, Stern DA, Wright AL, Billheimer D, Martinez FD. Asthma-associated differences in microbial composition of induced sputum. J Allergy Clin Immunol. 2013; 131:346-352. e1-e3. [PubMed: 23265859] 
34. Moore WC, Meyers DA, Wenzel SE, Teague WG, Li H, Li X, et al. Identification of asthma phenotypes using cluster analysis in the Severe Asthma Research Program. Am J Respir Crit Care Med. 2010; 181:315-323. [PubMed: 19892860]

35. Wu W, Bleecker E, Moore W, Busse WW, Castro M, Chung KF, et al. Unsupervised phenotyping of Severe Asthma Research Program participants using expanded lung data. J Allergy Clin Immunol. 2014; 133:1280-1288. [PubMed: 24589344]

36. Huang YJ, Boushey HA. The microbiome and asthma. Ann Am Thorac Soc. 2014; 11(Suppl 1):S48-S51. [PubMed: 24437406]

37. Green BJ, Wiriyachaiporn S, Grainge C, Rogers GB, Kehagia V, Lau L, et al. Potentially pathogenic airway bacteria and neutrophilic inflammation in treatment resistant severe asthma. PLoS One. 2014; 9:e100645. [PubMed: 24955983]

38. Huang YJ, Charlson ES, Collman RG, Colombini-Hatch S, Martinez FD, Senior RM. The role of the lung microbiome in health and disease. A National Heart, Lung, and Blood Institute workshop report. Am J Respir Crit Care Med. 2013; 187:1382-1387. [PubMed: 23614695]

39. Goleva E, Jackson LP, Harris JK, Robertson CE, Sutherland ER, Hall CF, et al. The effects of airway microbiome on corticosteroid responsiveness in asthma. Am J Respir Crit Care Med. 2013; 188:1193-1201. [PubMed: 24024497]

40. Gollwitzer ES, Saglani S, Trompette A, Yadava K, Sherburn R, McCoy KD, et al. Lung microbiota promotes tolerance to allergens in neonates via PD-L1. Nat Med. 2014; 20:642-647. [PubMed: 24813249]

41. Worldwide variation in prevalence of symptoms of asthma, allergic rhinoconjunctivitis, and atopic eczema: ISAAC. The International Study of Asthma and Allergies in Childhood (ISAAC) Steering Committee. Lancet. 1998; 351:1225-1232. [PubMed: 9643741]

42. Oddy WH. The long-term effects of breastfeeding on asthma and atopic disease. Adv Exp Med Biol. 2009; 639:237-251. [PubMed: 19227546]

43. Ball TM, Castro-Rodriguez JA, Griffith KA, Holberg CJ, Martinez FD, Wright AL. Siblings, daycare attendance, and the risk of asthma and wheezing during childhood. N Engl J Med. 2000; 343:538-543. [PubMed: 10954761]

44. von Hertzen L, Laatikainen T, Pitkanen T, Vlasoff T, Makela MJ, Vartiainen E, et al. Microbial content of drinking water in Finnish and Russian Karelia - implications for atopy prevalence. Allergy. 2007; 62:288-292. [PubMed: 17298346]

45. Bjorksten B, Naaber P, Sepp E, Mikelsaar M. The intestinal microflora in allergic Estonian and Swedish 2-year-old children. Clin Exp Allergy. 1999; 29:342-346. [PubMed: 10202341]

46. Bjorksten B, Sepp E, Julge K, Voor T, Mikelsaar M. Allergy development and the intestinal microflora during the first year of life. J Allergy Clin Immunol. 2001; 108:516-520. [PubMed: 11590374]

47. Kalliomaki M, Kirjavainen P, Eerola E, Kero P, Salminen S, Isolauri E. Distinct patterns of neonatal gut microflora in infants in whom atopy was and was not developing. J Allergy Clin Immunol. 2001; 107:129-134. [PubMed: 11150002]

48. Penders J, Thijs C, van den Brandt PA, Kummeling I, Snijders B, Stelma F, et al. Gut microbiota composition and development of atopic manifestations in infancy: the KOALA Birth Cohort Study. Gut. 2007; 56:661-667. [PubMed: 17047098]

49. Herbst T, Sichelstiel A, Schar C, Yadava K, Burki K, Cahenzli J, et al. Dysregulation of allergic airway inflammation in the absence of microbial colonization. Am J Respir Crit Care Med. 2011; 184:198-205. [PubMed: 21471101]

50. Atarashi K, Tanoue T, Shima T, Imaoka A, Kuwahara T, Momose Y, et al. Induction of colonic regulatory $\mathrm{T}$ cells by indigenous Clostridium species. Science. 2011; 331:337-341. [PubMed: 21205640]

51. Karimi K, Inman MD, Bienenstock J, Forsythe P. Lactobacillus reuteri-induced regulatory T cells protect against an allergic airway response in mice. Am J Respir Crit Care Med. 2009; 179:186193. [PubMed: 19029003]

52. Ivanov II, Atarashi K, Manel N, Brodie EL, Shima T, Karaoz U, et al. Induction of intestinal Th17 cells by segmented filamentous bacteria. Cell. 2009; 139:485-498. [PubMed: 19836068] 
53. Trompette A, Gollwitzer ES, Yadava K, Sichelstiel AK, Sprenger N, Ngom-Bru C, et al. Gut microbiota metabolism of dietary fiber influences allergic airway disease and hematopoiesis. Nat Med. 2014; 20:159-166. [PubMed: 24390308]

54. Jackson DJ, Gangnon RE, Evans MD, Roberg KA, Anderson EL, Pappas TE, et al. Wheezing rhinovirus illnesses in early life predict asthma development in high-risk children. Am J Respir Crit Care Med. 2008; 178:667-672. [PubMed: 18565953]

55. Holtzman MJ, Byers DE, Benoit LA, Battaile JT, You Y, Agapov E, et al. Immune pathways for translating viral infection into chronic airway disease. Adv Immunol. 2009; 102:245-276. [PubMed: 19477323]

56. Yoo J, Tcheurekdjian H, Lynch SV, Cabana M, Boushey HA. Microbial manipulation of immune function for asthma prevention: inferences from clinical trials. Proc Am Thorac Soc. 2007; 4:277282. [PubMed: 17607013]

57. Ichinohe T, Pang IK, Kumamoto Y, Peaper DR, Ho JH, Murray TS, et al. Microbiota regulates immune defense against respiratory tract influenza A virus infection. Proc Natl Acad Sci U S A. 2011; 108:5354-5359. [PubMed: 21402903]

58. Kitazawa H, Villena J. Modulation of Respiratory TLR3-Anti-Viral Response by Probiotic Microorganisms: Lessons Learned from Lactobacillus rhamnosus CRL1505. Front Immunol. 2014; 5:201. [PubMed: 24860569]

59. Yasui H, Kiyoshima J, Hori T. Reduction of influenza virus titer and protection against influenza virus infection in infant mice fed Lactobacillus casei Shirota. Clin Diagn Lab Immunol. 2004; 11:675-679. [PubMed: 15242940]

60. Fujimura KE, Johnson CC, Ownby DR, Cox MJ, Brodie EL, Havstad SL, et al. Man's best friend? The effect of pet ownership on house dust microbial communities. J Allergy Clin Immunol. 2010; 126:410-412. 2 e1-2 e3. [PubMed: 20633927]

61. Fujimura KE, Demoor T, Rauch M, Faruqi AA, Jang S, Johnson CC, et al. House dust exposure mediates gut microbiome Lactobacillus enrichment and airway immune defense against allergens and virus infection. Proc Natl Acad Sci U S A. 2014; 111:805-810. [PubMed: 24344318]

62. Leyer GJ, Li S, Mubasher ME, Reifer C, Ouwehand AC. Probiotic effects on cold and influenzalike symptom incidence and duration in children. Pediatrics. 2009; 124:e172-e179. [PubMed: 19651563]

63. Razi CH, Harmanci K, Abaci A, Ozdemir O, Hizli S, Renda R, et al. The immunostimulant OM-85 BV prevents wheezing attacks in preschool children. J Allergy Clin Immunol. 2010; 126:763-769. [PubMed: 20920766]

64. Luoto R, Ruuskanen O, Waris M, Kalliomaki M, Salminen S, Isolauri E. Prebiotic and probiotic supplementation prevents rhinovirus infections in preterm infants: a randomized, placebocontrolled trial. J Allergy Clin Immunol. 2014; 133:405-413. [PubMed: 24131826]

65. Rosenstreich DL, Eggleston P, Kattan M, Baker D, Slavin RG, Gergen P, et al. The role of cockroach allergy and exposure to cockroach allergen in causing morbidity among inner-city children with asthma. N Engl J Med. 1997; 336:1356-1363. [PubMed: 9134876]

66. Ahluwalia SK, Peng RD, Breysse PN, Diette GB, Curtin-Brosnan J, Aloe C, et al. Mouse allergen is the major allergen of public health relevance in Baltimore City. J Allergy Clin Immunol. 2013; 132:830-835. e1-e2. [PubMed: 23810154]

67. Platts-Mills TA, Erwin E, Heymann P, Woodfolk J. Is the hygiene hypothesis still a viable explanation for the increased prevalence of asthma? Allergy. 2005; 60(Suppl 79):25-31. [PubMed: 15842230]

68. Gern JE. The Urban Environment and Childhood Asthma study. J Allergy Clin Immunol. 2010; 125:545-549. [PubMed: 20226291]

69. Lynch SV, Wood RA, Boushey H, Bacharier LB, Bloomberg GR, Kattan M, et al. Effects of earlylife exposure to allergens and bacteria on recurrent wheeze and atopy in urban children. $\mathrm{J}$ Allergy Clin Immunol. 2014; 134:593-601. e12. [PubMed: 24908147]

70. Stefka AT, Feehley T, Tripathi P, Qiu J, McCoy K, Mazmanian SK, et al. Commensal bacteria protect against food allergen sensitization. Proc Natl Acad Sci U S A. 2014; 111:13145-13150. [PubMed: 25157157] 
71. Ober C, Yao TC. The genetics of asthma and allergic disease: a 21 st century perspective. Immunol Rev. 2011; 242:10-30. [PubMed: 21682736]

72. Sharma S, Chhabra D, Kho AT, Hayden LP, Tantisira KG, Weiss ST. The genomic origins of asthma. Thorax. 2014; 69:481-487. [PubMed: 24668408]

73. Turnbaugh PJ, Hamady M, Yatsunenko T, Cantarel BL, Duncan A, Ley RE, et al. A core gut microbiome in obese and lean twins. Nature. 2009; 457:480-484. [PubMed: 19043404]

74. Langille MG, Zaneveld J, Caporaso JG, McDonald D, Knights D, Reyes JA, et al. Predictive functional profiling of microbial communities using $16 \mathrm{~S}$ rRNA marker gene sequences. Nat Biotechnol. 2013; 31:814-821. [PubMed: 23975157] 


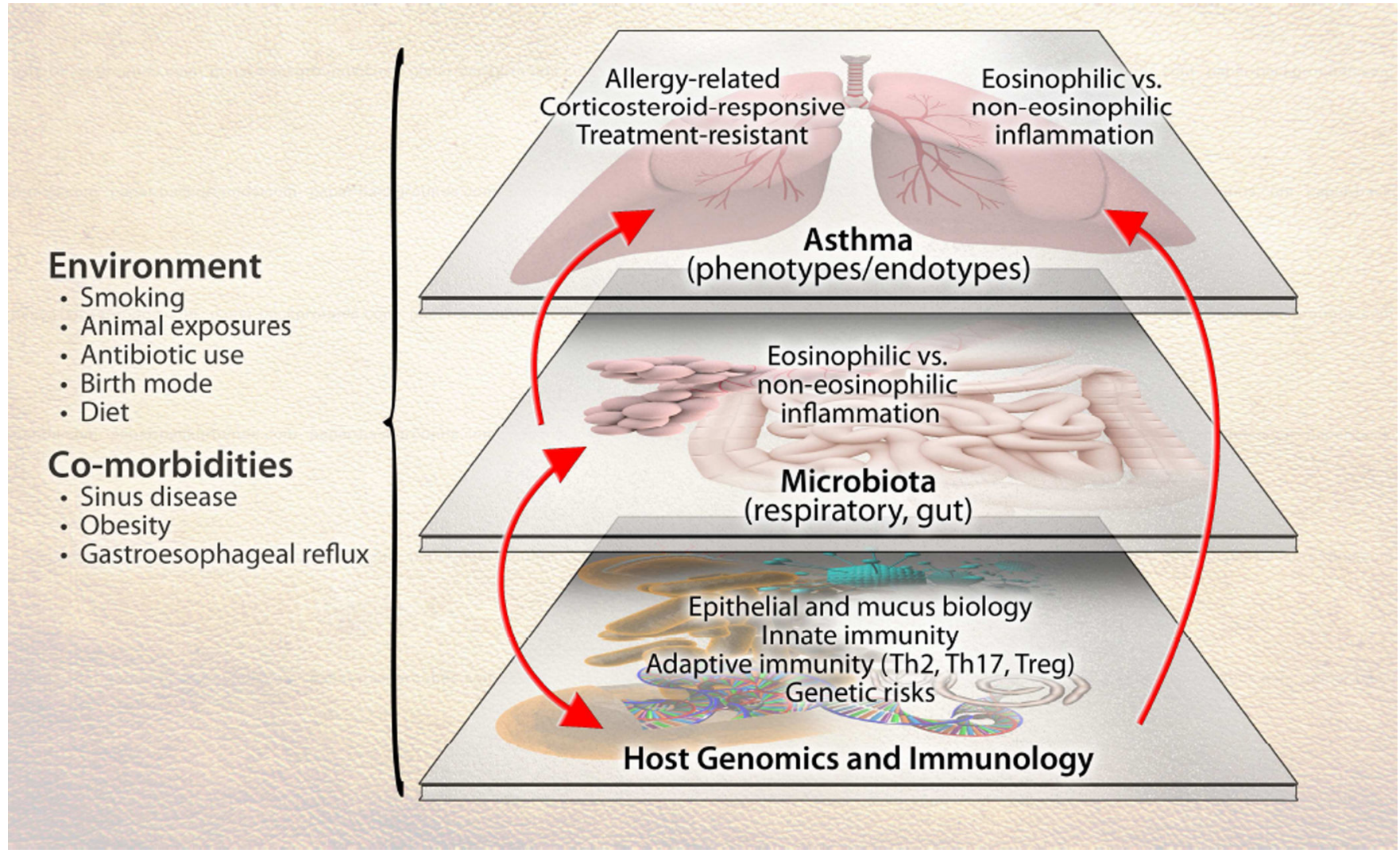

Figure 1.

The interface of microbiota interactions with other factors that collectively can influence susceptibility to asthma or its manifestations. Components of the depicted system - host genetics and immunology, microbiota, environmental exposures, and the disease of asthma are themselves heterogeneous entities, presenting challenges to more precisely dissect the role(s) of the microbiome in asthma. 